\title{
Aplikasi Pendeteksi Dini Penyakit Hepatitis Menggunakan Mesin Inferensi Forward Chaining Berbasis Android
}

\author{
Bambang Agus Herlambang ${ }^{1}$, Aditya Galih Prathama ${ }^{2}$, Rahmat Robi Waliyansyah ${ }^{3 *}$ \\ 1 Universitas PGRI Semarang/Informatika \\ 2 Universitas PGRI Semarang/Informatika \\ 3 Universitas PGRI Semarang/Informatika
}

\begin{abstract}
The development of the world of information technology or commonly known as IT is indeed extraordinary rapid that is in harmony with human needs one of which is helping medical staff to analyze the disease one of which is Hepatitis. Hepatitis is inflammation that occurs in the human liver and its types are Hepatitis A, Hepatitis $B$ and Hepatitis $C$. Application is a program developed to carry out certain functions for certain users who aim to achieve certain goals. On this occasion the authors developed the Hepatitis Disease Early Detection Application Using an Android-Based Forward Chaining Inference Machine to display the classification of Hepatitis A, Hepatitis B or Hepatitis $C$. The results obtained in this study are the Early Detection Application of Hepatitis Using the Android-Based Forward Chaining Inference Machine successfully designed to provide support in the form of convenience for doctors regarding the description of hepatitis that is Hepatitis A, Hepatitis B and Hepatitis $C$ and tested using Black Box testing with the results are feasible to use, the White Box test with the results of edges, nodes, predicate nodes and independent pathways is 22 and UAT testing with $92 \%$ results from 5 respondents.
\end{abstract}

Keywords: Hepatitis; Forward Chaining; Android

corresponding email : rahmat.robi.waliyansyah@upgris.ac.id

This is an open access article under the $\underline{C C B Y}$ license

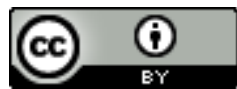

\section{INTRODUCTION}

Perkembangan dunia teknologi informasi atau biasa dikenal dengan TI memang luar biasa pesat selaras dengan kebutuhan manusia yang semakin berkembang tiap harinya [1]. Informasi yang dapat diperoleh melalui perkembangan dunia TI secara global yaitu internet melalui personal computer (PC), smartphone maupun tablet sangatlah cepat, tepat dan akurat merambah ke berbagai bidang kehidupan termasuk salah satunya pada bidang kesehatan [2]. Hadirnya perkembangan dunia TI tersebut diharapkan mampu memberikan sebuah aplikasi beserta metode tertentu dalam membantu tenaga medis menganalisa penyakit salah satunya adalah Hepatitis tersebut [3].

Hepatitis adalah suatu istilah yang merujuk kepada peradangan yang terjadi pada hati manusia [4]. Terdapat beberapa jenis hepatitis yang dikenal di Indonesia yaitu Hepatitis A, Hepatitis B dan Hepatitis C [5]. Hepatitis pada dasarnya disebabkan oleh infeksi virus, meskipun sebenarnya dapat juga disebabkan oleh faktor lain seperti alkohol, penyakit autoimun, zat racun dan obat - obatan tertentu [6]. Penyakit tersebut bertanggung jawab atas kematian $1-2$ juta penduduk setiap tahunnya dan hepatitis A masih merupakan bagian terbesar dari kasus hepatitis yaitu berkisar dari $39,8 \%$ sampai $68,3 \%$ [7].

Aplikasi deteksi dini merupakan suatu program yang dikembangkan untuk melaksanakan fungsi tertentu bagi pengguna tertentu yang bertujuan untuk mencapai tujuan tertentu. Hadirnya suatu aplikasi diharapkan mampu untuk menyelesaikan masalah yang dihadapi dengan cepat dan tepat [8].

Bidang kesehatan merupakan suatu ilmu yang terus berupaya untuk memelihara kesehatan manusia termasuk di dalamnya upaya penanggulangan, upaya pencegahan hingga upaya perawatan kesehatan mulai dari sejak lahir hingga usia senja dan salah satu masalah kesehatan yang cukup mendapat perhatian adalah Hepatitis karena penyakit tersebut dapat terjadi akibat infeksi virus maupun faktor lain yang menyerang hati manusia [9].

\section{LITERATURE REVIEW}

Beberapa penelitian mengenai aplikasi besertametode Forward Chaining ini telah banyak dilakukan oleh mahasiswa diantaranya Arief Budiman, Pradityo Utomo, dan Sri Rahayu dari Fakultas Pertanian Universitas 
JAST : Journal of Applied Science and Technology

Volume. 1 Number. 2, July 2021

ISSN : 2775-4022

http://jurnal.unissula.ac.id/index.php/JAST

Merdeka Madiun tahun 2019 yaitu Pengembangan Aplikasi Deteksi Dini Serangan Hama Padi Berbasis Android yang bertujuan untuk mengidentifikasi secara dini ancaman dari serangan hama [1]. serta Surawijaya Surahman dan Eko Budi Setiawan dari Universitas Komputer Indonesia Bandung tahun 2017 yaitu tentang aplikasi Mobile Driver berbasis android Dengan menggunakan aplikasi mobile, maka dapat dengan mudah melakukan berbagai macam aktifitas mulai dari hiburan, berjualan, belajar, mengerjakan pekerjaan kantor, browsing dan lain sebagainya [10]. Ada pula penelitian mengenai Aplikasi diagnosa penyakit yang dilakukan oleh Indrajani, Raymond Bahana, Raymond Kosala, dan Yaya Heryadi dari Bina Nusantara University Jakarta tahun 2018 yaitu Aplikasi Informasi Kesehatan dan Diagnosa Penyakit Jantung Berbasis Android dan bagaimana cara penyembuhannya [11].

Hepatitis adalah suatu istilah yang merujuk kepada peradangan yang terjadi pada hati manusia. Terdapat beberapa jenis hepatitis yang dikenal di Indonesia yaitu Hepatitis A (HAV), Hepatitis B (HBV) dan Hepatitis C (HCV) [3]. Hepatitis yang terjadi dapat berubah menjadi akut atau kronis [12]. Seseorang yang mengalami hepatitis dapat menjadi akut dapat menyebabkan gagal hati dan seseorang yang mengalami hepatitis kronis dapat menyebabkan sirosis dan kanker hati [13]. Hepatitis dapat mengganggu berbagai fungsi tubuh manusia terutama yang sangat berkaitan dengan metabolisme karena seperti yang kita ketahui bersama bahwa hati memiliki peranan penting yaitu menghasilkan empedu untuk pencernaan lemak, menguraikan karbohidrat, lemak dan protein, menetralisir racun yang masuk ke dalam tubuh, mengaktifkan berbagai enzim, membuang bilirubin (zat yang membuat tubuh menjadi kuning), kolesterol, hormon dan obat - obatan, membentuk protein seperti albumin dan faktor pembekuan darah, menyimpan karbohidrat dalam bentuk glikogen, vitamin dan mineral [14].

Tabel 1. Gejala hepatitis [2]

\begin{tabular}{|c|c|}
\hline Nama Penyakit & Gejala Penyakit \\
\hline \multirow{11}{*}{ Hepatitis A } & Infeksi virus Hepatitis A \\
\hline & Akibat memakan makanan yang tercemar \\
\hline & Akibat meminum minuman yang tercemar \\
\hline & $\begin{array}{l}\text { Mengalami gejala flu misalnya mual, muntah, } \\
\text { demam dan lemas }\end{array}$ \\
\hline & Feses berwarna pucat \\
\hline & Mata dan kulit berubah menjadi kekuningan \\
\hline & Nyeri perut \\
\hline & Berat badan turun \\
\hline & Urin menjadi gelap seperti teh \\
\hline & Kehilangan nafsu makan \\
\hline & $\begin{array}{l}\text { Masa inkubasi virus Hepatitis A membutuhkan waktu } \\
15-45 \text { hari }\end{array}$ \\
\hline \multirow{12}{*}{ Hepatitis B } & Infeksi virus Hepatitis B \\
\hline & $\begin{array}{l}\text { Mengalami gejala flu misalnya mual, muntah, } \\
\text { demam dan lemas }\end{array}$ \\
\hline & Feses berwarna pucat \\
\hline & Mata dan kulit berbuah menjadi kekuningan \\
\hline & Nyeri perut \\
\hline & Berat badan turun \\
\hline & Urin menjadi gelap seperti teh \\
\hline & Kehilangan nafsu makan \\
\hline & Akibat penggunaan narkotika melalui jarum suntik \\
\hline & Akibat berganti pasangan seksual \\
\hline & Menerima transfusi darah yang tidak steril \\
\hline & $\begin{array}{l}\text { Masa inkubasi Hepatitis B membutuhkan waktu } 45- \\
60 \text { hari }\end{array}$ \\
\hline \multirow{7}{*}{ Hepatitis C } & Infeksi virus Hepatitis $\mathrm{C}$ \\
\hline & $\begin{array}{l}\text { Mengalami gejala flu misalnya mual, muntah, } \\
\text { demam dan lemas }\end{array}$ \\
\hline & Feses berwarna pucat \\
\hline & Mata dan kulit berbuah menjadi kekuningan \\
\hline & Nyeri perut \\
\hline & Berat badan turun \\
\hline & Urin menjadi gelap seperti teh \\
\hline
\end{tabular}


JAST : Journal of Applied Science and Technology

Volume. 1 Number. 2, July 2021

ISSN : 2775-4022

http://jurnal.unissula.ac.id/index.php/JAST

\begin{tabular}{ll}
\hline Nama Penyakit & \multicolumn{1}{c}{ Gejala Penyakit } \\
\hline & Kehilangan nafsu makan \\
\cline { 2 - 2 } & Pengguna narkotika melalui jarum suntik \\
\cline { 2 - 2 } & Berganti pasangan seksual \\
\cline { 2 - 2 } & Menerima transfusi darah yang tidak steril \\
\cline { 2 - 2 } & $\begin{array}{l}\text { Masa inkubasi Hepatitis C membutuhkan waktu 2 } \\
\text { minggu }-6 \text { bulan. }\end{array}$ \\
\hline
\end{tabular}

Tabel 2. Pengobatan hepatitis [13]

\begin{tabular}{|c|c|}
\hline $\begin{array}{c}\text { Nama } \\
\text { Penyakit }\end{array}$ & Pengobatan Penyakit \\
\hline \multirow{4}{*}{ Hepatitis A } & Pemantauan kondisi fisik pasien selama masa penyembuhan sangat diperlukan \\
\hline & Menghindari aktivitas fisik yang melelahkan \\
\hline & Menjaga asupan cairan tubuh dengan banyak minum air putih \\
\hline & Menjaga kebersihan bahan makanan \\
\hline \multirow{5}{*}{ Hepatitis B } & Pemantauan kondisi fisik pasien selama masa penyembuhan sangat diperlukan \\
\hline & Menghindari aktivitas fisik yang melelahkan \\
\hline & Menjaga asupan cairan tubuh dengan banyak minum air putih \\
\hline & Menjaga kebersihan bahan makanan \\
\hline & Apabila kronis, akan diberikan obat - obatan untuk memusnahkan virus dari dalam tubuh \\
\hline \multirow{5}{*}{ Hepatitis C } & Pemantauan kondisi fisik pasien selama masa penyembuhan sangat diperlukan \\
\hline & Menghindari aktivitas fisik yang melelahkan \\
\hline & Menjaga asupan cairan tubuh dengan banyak minum air putih \\
\hline & Menjaga kebersihan bahan makanan \\
\hline & $\begin{array}{l}\text { Apabila kronis, akan diberikan obat - obatan untuk memusnahkan virus dari dalam tubuh salah } \\
\text { satunya interferon }\end{array}$ \\
\hline
\end{tabular}

Pencegahan Hepatitis [15] :

1. Menjaga kebersihan sumber air agar terhindar dari virus hepatitis.

2. Mencuci bahan - bahan makanan yang akan dikonsumsi terutama kerang dan tiram, sayuran dan buah buahan.

3. Mengurangi konsumsi alkohol.

4. Mengurangi konsumsi rokok.

5. Melakukan hubungan seksual misal dengan memakai kondom atau tidak berganti pasangan.

6. Tidak berbagi sikat gigi atau jarum suntik dengan orang lain.

7. Tidak menyentuh tumpahan darah tanpa sarung tangan pelindung

Metode Forward Chaining adalah metode yang melakukan pencarian beralur maju atau teknik pelacakan ke depan yang dimulai dengan mengumpulkan fakta - fakta disertai dengan penggabungan rule untuk menghasilkan suatu kesimpulan atau tujuan [16]. Forward Chaining dimulai dengan fakta yang diketahui dengan menggunakan rule IF kemudian lakukan pencocokan dengan fakta lainnya, apabila ada fakta yang cocok maka gunakan rule AND. Setelah kedua rule tersebut tereksekusi maka lahirlah fakta baru yang disebut dengan rule THEN. Setiap rule yang ada pada metode forward chaining ini hanya boleh dieksekusi sebanyak 1 (satu) kali.

Model pengembangan Waterfall pada gambar 1 adalah sebuah software process models (model proses pengembangan perangkat lunak) yang telah lama digunakan dalam dunia pengembangan perangkat lunak. Model pengembangan ini menerapkan langkah - langkah rekayasa perangkat lunak secara sekuensial atau setahap demi setahap mulai dari tahap Requirements Definition, System and Software Design, Implementation and Unit Testing, Integration and System Testing, Operation and Maintenance [17]. Keuntungan yang didapat menggunakan model pengembangan Waterfall pada Gambar 1 mengumpulkan semua requirements (kebutuhan perangkat lunak yang akan dikembangkan) secara keseluruhan diawal beserta dengan jadwal yang dikehendaki lalu memulai mengembangkan perangkat lunak menggunakan tahapan Requirements Definition, System and Software Design, Implementation and Unit Testing, Integration and System Testing, Operation and Maintenance sehingga semua proses yang ada harus terlewati satu per satu tanpa terkecuali. 


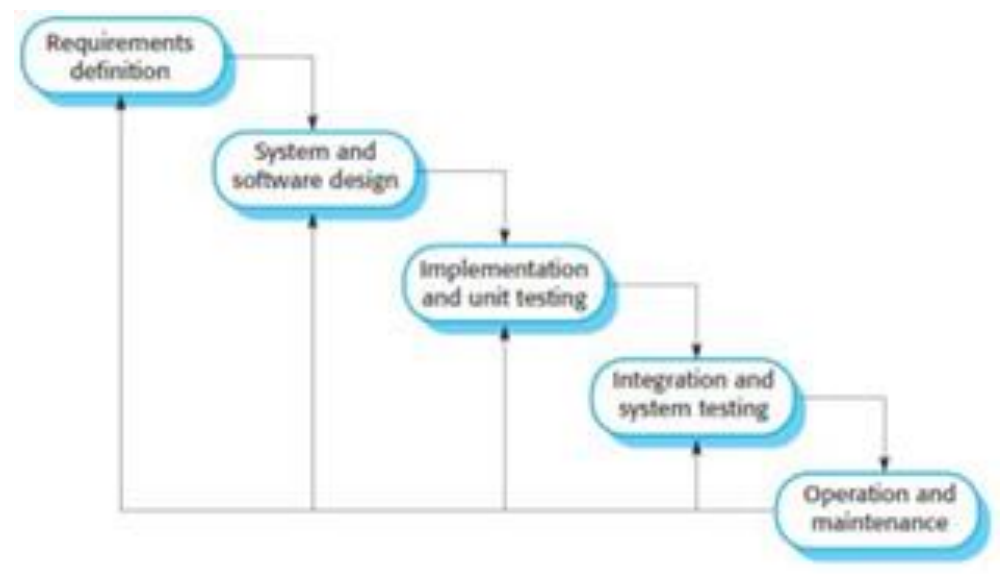

Gambar 1. Model Waterfall

\section{RESEARCH METHOD}

Model pengembangan dalam konsep OOP yang dimaksud dalam penelitian ini adalah yang sesuai dengan tahapan model pengembangan Waterfall. Berikut ini adalah penjelasan singkat mengenai tahapan model Waterfall untuk pengembangan aplikasi diantaranya adalah:

a. Tahapan Requirements Definition yaitu melakukan penelusuran dan observasi secara jurnal mahasiswa maupun media website serta wawancara dengan cara tanya jawab dengan pakar yang mengetahui seputar penyakit Hepatitis A, Hepatitis B atau Hepatitis C terkait dengan pengembangan aplikasi dan metode Forward Chaining berbasis Android.

b. Tahapan System and Software Design yaitu melakukan analisis sistem yang terkait dengan kebutuhan fungsional dan kebutuhan non fungsional yang nantinya digunakan sebagai sarana untuk estimasi pengembangan Aplikasi Pendeteksi Dini Penyakit Hepatitis Menggunakan Mesin Inferensi Forward Chaining Berbasis Android serta melakukan pemodelan aplikasi dari segi analisa dalam bentuk notasi UML yang terdiri dari Use Case Diagram, Class Diagram, Activity Diagram dan Sequence Diagram serta dari segi desain yang terdiri dari perancangan antarmuka, perancangan basis data dan perancangan pengujian menggunakan Black Box dengan metode Forward Chaining disertai model pengembangan Waterfall berbasis Android.

c. Tahapan Implementation and Unit Testing yaitu melakukan pengembangan aplikasi sebagai 1 (satu) set program lalu menggunakan unit testing untuk melakukan verifikasi apakah sudah sesuai berdasarkan dari tahapan pemodelan yang telah disusun sebelumnya.

d. Tahapan Integration and System Testing yaitu melakukan penyatuan keseluruhan program yang telah dikembangkan lalu memberikan pengujian menggunakan Black Box untuk memastikan bahwa aplikasi sudah sesuai dengan kebutuhan dan merilis aplikasi tersebut.

e. Tahapan Operation and Maintenance yaitu melakukan instalasi beserta dengan dokumentasi penggunaan aplikasi tersebut dan monitoring penggunaan aplikasi serta melaporkan error yang terjadi apabila ada.

\section{RESULT AND ANALYSIST}

Tahap Requirements Definition berisi tentang pengumpulan seluruh data - data yang dibutuhkan secara lengkap baik dari sisi penelusuran dokumen - dokumen melalui website tertentu maupun mengadakan wawancara dengan pakar tertentu untuk menentukan kebutuhan - kebutuhan yang akan digunakan pada aplikasi yaitu kebutuhan Hepatitis A, Hepatitis B dan Hepatitis C serta kebutuhan fungsionalitas lainnya yaitu hal apa saja yang dapat dilakukan oleh aplikasi tersebut.

Tahap System and Software Design berisi tentang rancangan analisa sistem secara keseluruhan setelah mendapatkan kebutuhan - kebutuhan dari tahap pengumpulan kebutuhan sistem yaitu menjabarkan lebih spesifik mengenai gejala Hepatitis A, Hepatitis B dan Hepatitis C serta mendefinisikan fungsionalitas aplikasi lainnya yaitu penentuan user aplikasi yang terdiri dari Pengembang Aplikasi dan Pengguna Aplikasi beserta hal - hal apa sajakah yang dapat mereka lakukan terhadap aplikasi tersebut serta pemodelan aplikasi secara bertahap setelah mendapatkan kebutuhan - kebutuhan dari tahap analisa sistem yaitu dalam bentuk notasi UML yang terdiri dari Use Case Diagram, Class Diagram, Activity Diagram dan Sequence Diagram serta perancangan antarmuka, perancangan basis data dan perancangan pengujian dapat dilihat pada gambar 2 sampai 14 dan Tabel 3 sampai 6 . 
JAST : Journal of Applied Science and Technology

Volume. 1 Number. 2, July 2021

ISSN : 2775-4022

http://jurnal.unissula.ac.id/index.php/JAST

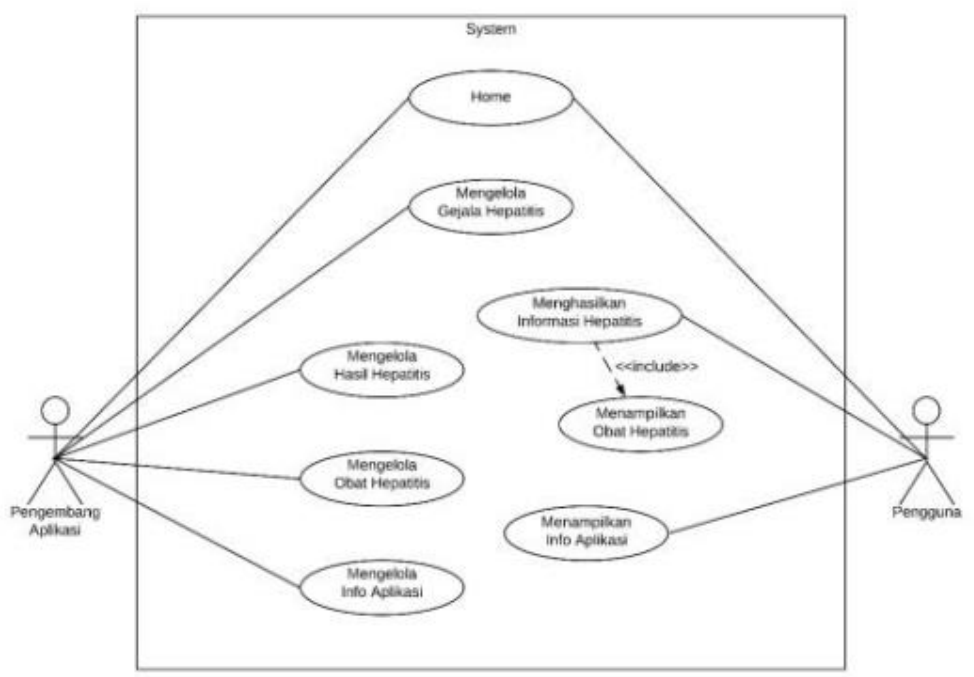

Gambar 2. Use Case Diagram System

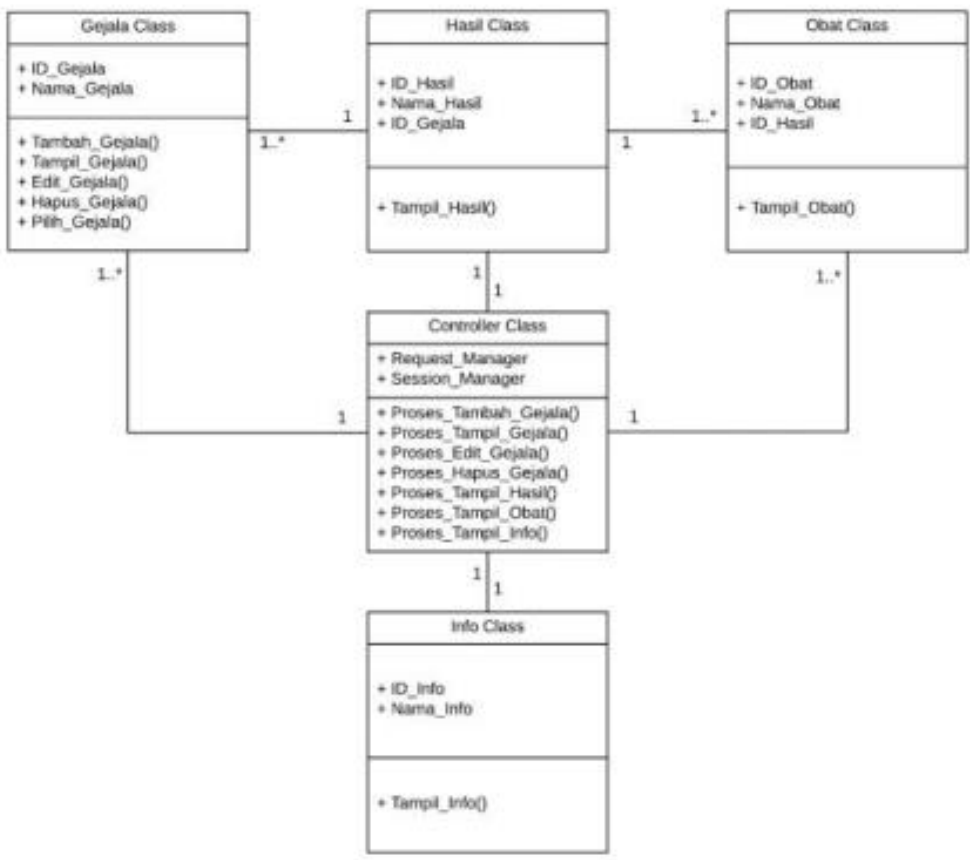

Gambar 3. Class Diagram System

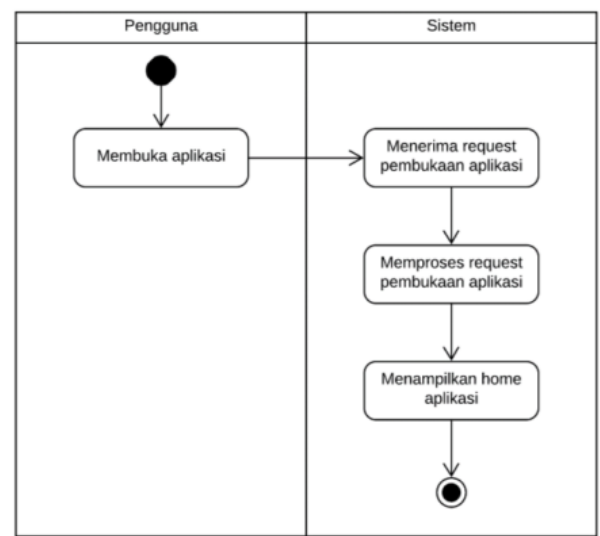

Gambar 4. Activity Diagram Home 


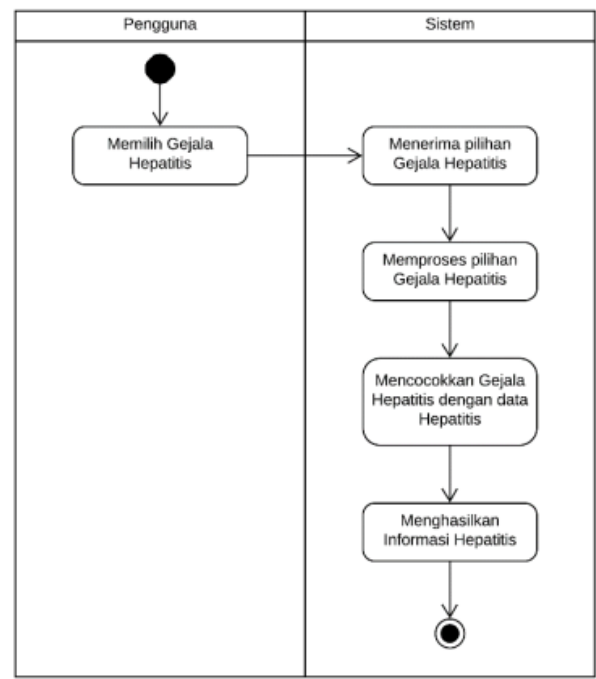

Gambar 5. Activity Diagram Menghasilkan Informasi Hepatitis

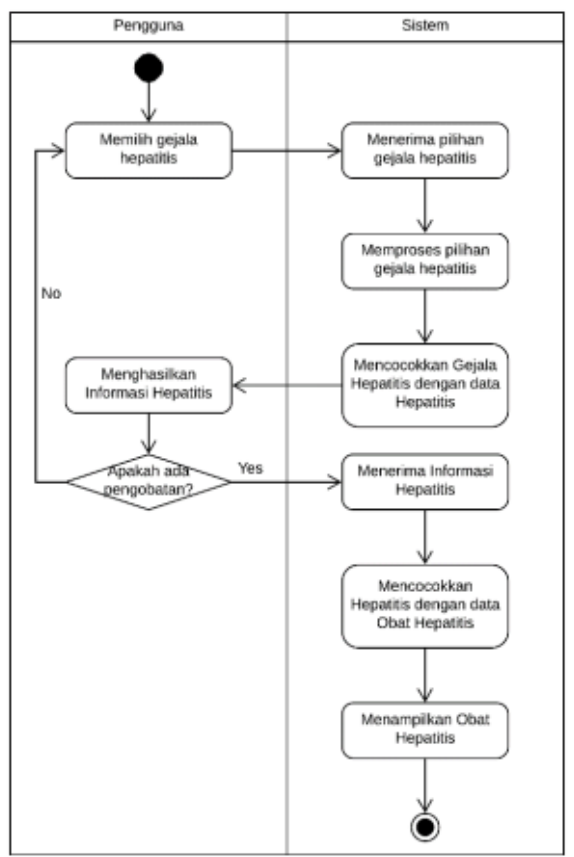

Gambar 6. Activity Diagram Menampilkan Obat Hepatitis

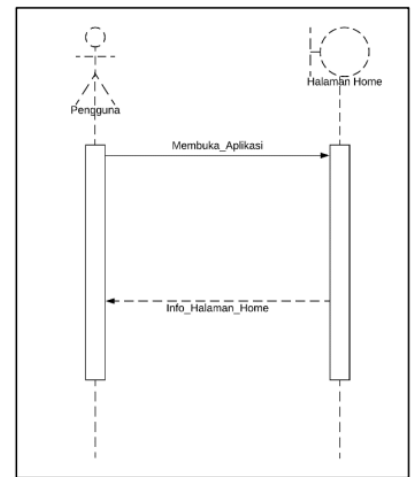

Gambar 7. Sequence Diagram Membuka Aplikasi 


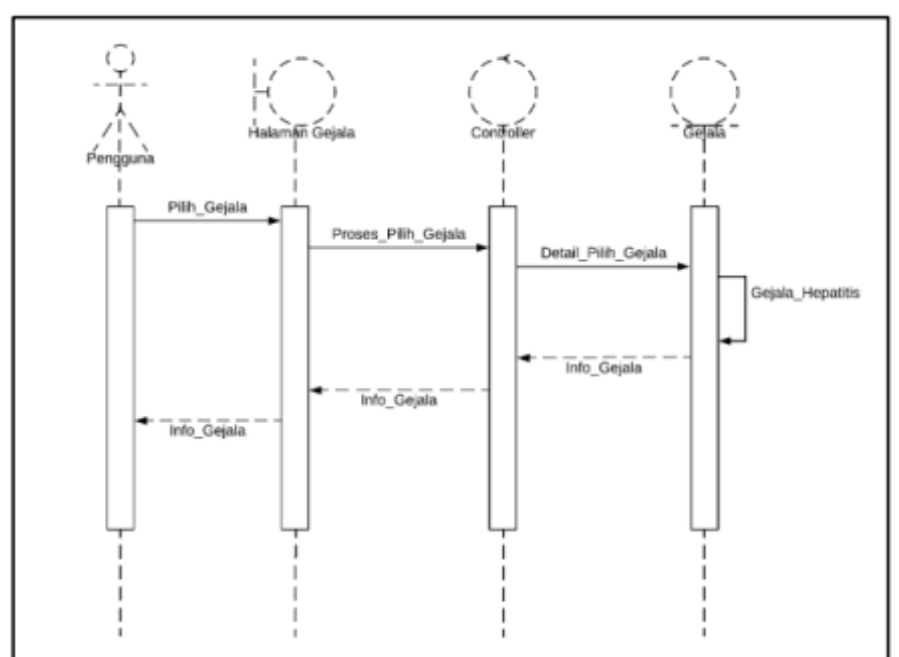

Gambar 8. Sequence Diagram Menghasilkan Informasi Hepatitis

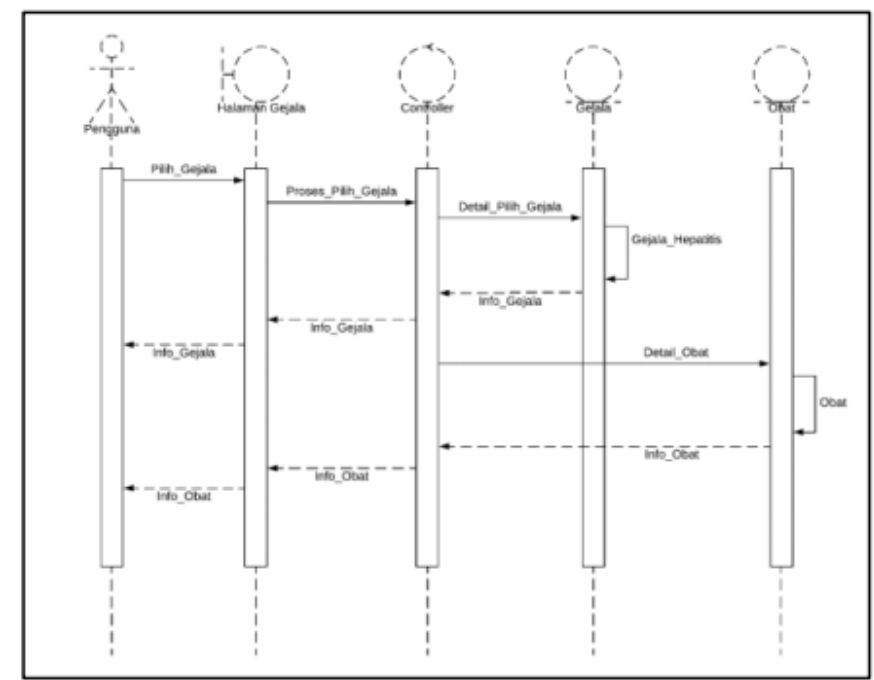

Gambar 9. Sequence Diagram Menampilkan Obat Hepatitis

Tahap Implementation and Unit Testing berisi tentang pengembangan aplikasi sebagai 1 (satu) set aplikasi secara keseluruhan oleh Pengembang Aplikasi hingga selesai dan dapat di install pada smartphone Android.

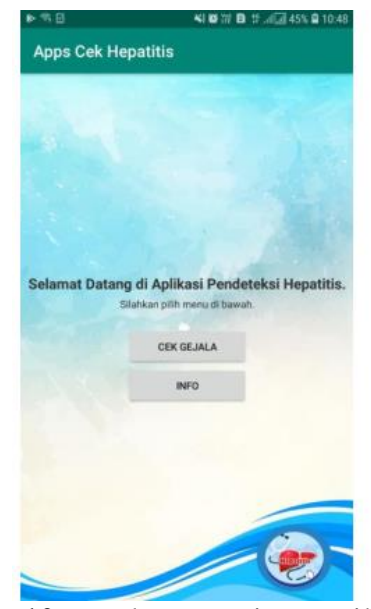

Gambar 10. Implementasi Tampilan Home 


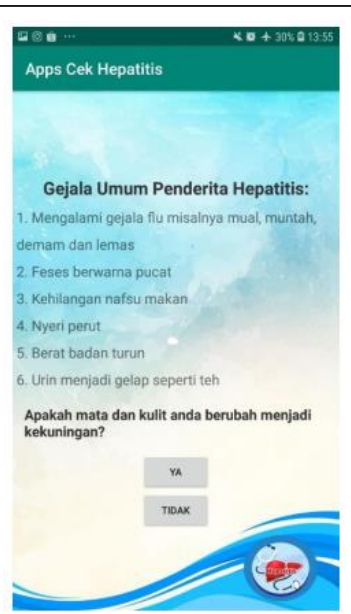

Gambar 11. Implementasi Tampilan Pemrosesan Hepatitis

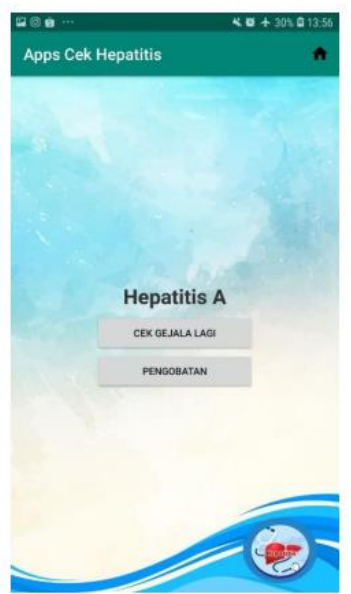

Gambar 12. Implementasi Tampilan Hasil Hepatitis

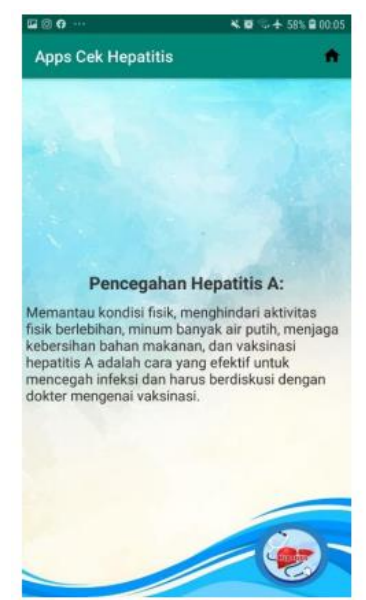

Gambar 13. Implementasi Tampilan Informasi Pengobatan

Tahap Integration and System Testing berisi pengujian menggunakan Black Box, White Box dan User Acceptance Test serta memastikan bahwa Pengguna Aplikasi dapat menggunakannya secara optimal. 
JAST : Journal of Applied Science and Technology

Volume. 1 Number. 2, July 2021

ISSN : 2775-4022

http://jurnal.unissula.ac.id/index.php/JAST

Tabel 3. Black Box Testing

\begin{tabular}{|c|c|c|c|}
\hline Pengujian & Skenario & Hasil yang diharapkan & $\begin{array}{l}\text { Hasil } \\
\text { akhir }\end{array}$ \\
\hline Uji Home & $\begin{array}{l}\text { Pengembang Aplikasi dan } \\
\text { Pengguna mengakses } \\
\text { Halaman Home tanpa perlu } \\
\text { username dan password }\end{array}$ & $\begin{array}{l}\text { Sistem dapat menampilkan halaman Home } \\
\text { bagi Pengembang Aplikasi dan Pengguna }\end{array}$ & Sukses \\
\hline $\begin{array}{l}\text { Uji Mengelola } \\
\text { Gejala Hepatitis }\end{array}$ & $\begin{array}{l}\text { Pengembang Aplikasi dapat } \\
\text { menambah atau mengedit atau } \\
\text { menghapus Gejala Hepatitis } \\
\text { yang diperlukan }\end{array}$ & $\begin{array}{l}\text { Sistem dapat menampilkan halaman tambah } \\
\text { atau halaman edit } \\
\text { atau halaman hapus Gejala Hepatitis }\end{array}$ & Sukses \\
\hline $\begin{array}{l}\text { Uji Mengelola } \\
\text { Hasil Hepatitis }\end{array}$ & $\begin{array}{l}\text { Pengembang Aplikasi dapat } \\
\text { menambah atau mengedit atau } \\
\text { menghapus Hasil Hepatitis yang } \\
\text { diperlukan }\end{array}$ & $\begin{array}{l}\text { Sistem dapat menampilkan halaman tambah } \\
\text { atau halaman edit } \\
\text { atau halaman hapus Hasil } \\
\text { Hepatitis }\end{array}$ & Sukses \\
\hline $\begin{array}{l}\text { Uji Mengelola } \\
\text { Obat Hepatitis }\end{array}$ & $\begin{array}{l}\text { Pengembang Aplikasi dapat } \\
\text { menambah atau mengedit atau } \\
\text { menghapus Obat Hepatitis yang } \\
\text { diperlukan }\end{array}$ & $\begin{array}{l}\text { Sistem dapat menampilkan halaman tambah } \\
\text { atau halaman edit } \\
\text { atau halaman hapus Obat Hepatitis }\end{array}$ & Sukses \\
\hline $\begin{array}{l}\text { Uji Mengelola Info } \\
\text { Aplikasi }\end{array}$ & $\begin{array}{l}\text { Pengembang Aplikasi dapat } \\
\text { menambah atau mengedit atau } \\
\text { menghapus Info Hepatitis yang } \\
\text { diperlukan }\end{array}$ & $\begin{array}{l}\text { Sistem dapat menampilkan halaman tambah } \\
\text { atau halaman edit } \\
\text { atau halaman hapus Info Hepatitis }\end{array}$ & Sukses \\
\hline $\begin{array}{l}\text { Uji Menghasilkan } \\
\text { Informasi } \\
\text { Hepatitis }\end{array}$ & $\begin{array}{l}\text { Pengguna memilih Gejala } \\
\text { Hepatitis dengan cara memilih } \\
\text { jawaban Ya } \\
\text { atau Tidak dan mengetahui } \\
\text { Informasi Hepatitis }\end{array}$ & $\begin{array}{l}\text { Sistem memproses pilihan Gejala Hepatitis } \\
\text { dengan mencocokkan ke dalam basis data } \\
\text { dan menampilkan Informasi Hepatitis }\end{array}$ & Sukses \\
\hline $\begin{array}{l}\text { Uji Menampilkan } \\
\text { Obat Hepatitis }\end{array}$ & $\begin{array}{l}\text { Pengguna memilih Gejala } \\
\text { Hepatitis dengan cara memilih } \\
\text { jawaban Ya } \\
\text { atau Tidak dan mengetahui } \\
\text { Informasi Hepatitis beserta } \\
\text { dengan info Obat Hepatitis }\end{array}$ & $\begin{array}{l}\text { Sistem memproses pilihan Gejala Hepatitis } \\
\text { dengan mencocokkan ke dalam basis data } \\
\text { dan menampilkan Informasi Hepatitis } \\
\text { beserta dengan info Obat Hepatitis }\end{array}$ & Sukses \\
\hline $\begin{array}{l}\text { Uji Menampilkan } \\
\text { Info Aplikas }\end{array}$ & $\begin{array}{lrr}\begin{array}{l}\text { Pengembang } \\
\text { mengakses }\end{array} & \begin{array}{l}\text { Aplikasi } \\
\text { halaman }\end{array} & \text { dapat } \\
\text { Aplikasi } & & \\
\end{array}$ & $\begin{array}{l}\text { Sistem dapat menampilkan halaman Info } \\
\text { Aplikasi }\end{array}$ & Sukses \\
\hline
\end{tabular}

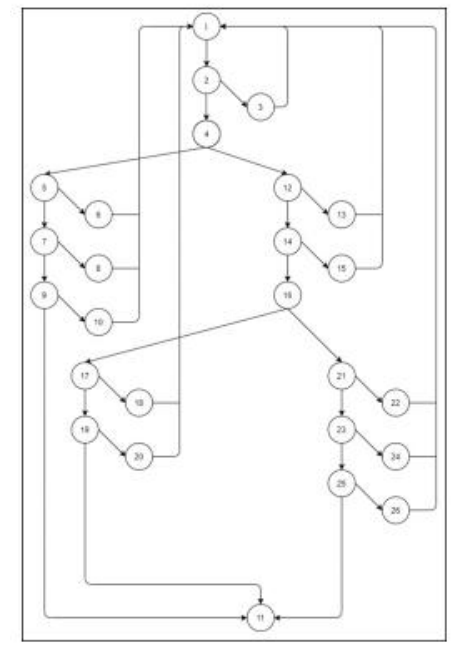

Gambar 14. Basis Path Testing pada White Box Testing 
JAST : Journal of Applied Science and Technology

Volume. 1 Number. 2, July 2021

ISSN : 2775-4022

http://jurnal.unissula.ac.id/index.php/JAST

Cyclomatic Complexity pada White Box Testing

$\mathrm{V}(\mathrm{G})=\mathrm{E}-\mathrm{N}+2=38-26+2=14$

$\mathrm{E}$ : jumlah edge pada flowgraph

$\mathrm{N}$ : jumlah node pada flowgraph

$\mathrm{V}(\mathrm{G})=\mathrm{P}+1=13+1=14$

$\mathrm{P}$ : jumlah predicate node pada flowgraph

Sehingga jalur independent Aplikasi Pendeteksi Dini Penyakit Hepatitis Menggunakan Mesin Inferensi Forward Chaining Berbasis Android yaitu:
a. Jalur 1 adalah 1, 2,3,1
b. Jalur 2 adalah $1,2,4,5,6,1$
c. Jalur 3 adalah $1,2,4,5,7,8,1$
d. Jalur 4 adalah $1,2,4,5,7,9,10,1$
e. Jalur 5 adalah $1,2,4,5,7,9,11$
f. Jalur 6 adalah 1, 2, 4, 12, 13, 1
g. Jalur 7 adalah $1,2,4,12,14,15,1$
h. Jalur 8 adalah $1,2,4,12,14,16,17,18,1$
i. Jalur 9 adalah $1,2,4,12,14,16,17,19,20,1$
j. Jalur 10 adalah 1, 2, 4, 12, 14, 16, 17, 19, 11
k. Jalur 11 adalah 1, 2, 4, 12, 14, 16, 21, 22, 1
1. Jalur 12 adalah 1, 2, 4, 12, 14, 16, 21, 23, 24, 1
m. Jalur 13 adalah 1, 2, 4, 12, 14, 16, 21, 23, 25, 26, 1
n. Jalur 14 adalah $1,2,4,12,14,16,21,23,25,11$

Tabel 4. UAT dari segi Format

\begin{tabular}{llll}
\hline \multirow{2}{*}{ Responden } & \multicolumn{3}{c}{ Materi dan skor } \\
\cline { 2 - 4 } & \multicolumn{1}{c}{2} & 3 \\
\hline Dokter & 4 & 5 & 5 \\
\hline Masyarakat & 5 & 5 & 5 \\
\hline Masyarakat & 4 & 4 & 5 \\
\hline Masyarakat & 4 & 5 & 5 \\
\hline Masyarakat & 4 & 5 & 4 \\
\hline Jumlah & 21 & 24 & 24 \\
\hline Persentase (\%) & $84 \%$ & $96 \%$ & $96 \%$ \\
\hline Rata - rata Persentase (\%) & & $92 \%$ & \\
\hline
\end{tabular}

Tabel 5. UAT dari segi kemudahan pengguna (Ease of Use)

\begin{tabular}{llll}
\hline \multirow{2}{*}{ Responden } & \multicolumn{3}{c}{ Materi dan skor } \\
\cline { 2 - 4 } & \multicolumn{1}{c}{1} & 2 & 3 \\
\hline Dokter & 5 & 5 & 5 \\
\hline Masyarakat & 3 & 4 & 4 \\
\hline Masyarakat & 4 & 4 & 5 \\
\hline Masyarakat & 5 & 5 & 5 \\
\hline Masyarakat & 4 & 4 & 4 \\
\hline Jumlah & 21 & 22 & 23 \\
\hline Persentase (\%) & $84 \%$ & $88 \%$ & $92 \%$ \\
\hline Rata - rata Persentase (\%) & \multicolumn{5}{l}{$88 \%$} \\
\hline
\end{tabular}

Tabel 6. UAT dari segi Usefulness

\begin{tabular}{lcccc}
\hline \multirow{2}{*}{ Responden } & \multicolumn{5}{c}{ Materi dan skor } \\
\cline { 2 - 5 } & 1 & 2 & 3 & 4 \\
\hline Dokter & 5 & 5 & 5 & 5 \\
\hline Masyarakat & 5 & 4 & 5 & 4 \\
\hline
\end{tabular}




\begin{tabular}{lllll}
\hline \multirow{2}{*}{\multicolumn{1}{c}{ Responden }} & \multicolumn{4}{c}{ Materi dan skor } \\
\cline { 2 - 5 } & \multicolumn{1}{c}{1} & 2 & 3 & 4 \\
\hline Masyarakat & 4 & 5 & 4 & 5 \\
\hline Masyarakat & 5 & 5 & 5 & 5 \\
\hline Masyarakat & 5 & 5 & 4 & 5 \\
\hline Jumlah & 24 & 24 & 23 & 24 \\
\hline Persentase (\%) & $96 \%$ & $96 \%$ & $92 \%$ & $96 \%$ \\
\hline Rata - rata Persentase (\%) & \multicolumn{5}{c}{$95 \%$} \\
\hline
\end{tabular}

Dari hasil rata-rata presentase tersebut dapat diketahui persentase ketercapaian sebagai berikut :

Hasil Akhir : total rata-rata $(\%) /$ jumlah aspek

$: 92 \%+88 \%+95 \% / 3$

$: 275 / 3$

$: 91,66 \%$ (dibulatkan ke atas) $=92 \%$

Tahapan Operation and Maintenance berisi tentang monitoring penggunaan aplikasi tersebut oleh Pengguna Aplikasi dan monitoring serta melaporkan error yang terjadi apabila ada kepada Pengembang Aplikasi agar segera diperbaiki sesegera mungkin.

\section{CONCLUSION}

1. Aplikasi Pendeteksi Dini Penyakit Hepatitis Menggunakan Mesin Inferensi Forward Chaining Berbasis Android berhasil dirancang untuk memberikan dukungan berupa kemudahan bagi dokter mengenai gambaran klasifikasi penyakit yaitu Hepatitis A, Hepatitis B dan Hepatitis C menggunakan metode Forward Chaining berbasis teknologi dengan tidak menghilangkan peran dokter beserta cara dokter dalam melakukan diagnosa penyakit.

2. Berdasarkan pengujian Black Box, Aplikasi Pendeteksi Dini Penyakit Hepatitis Menggunakan Mesin Inferensi Forward Chaining Berbasis Android ini layak untuk digunakan dengan persentase mencapai $100 \%$ dan dapat berfungsi dengan baik.

3. Berdasarkan pengujian White Box, hasil perhitungan Cyclomatic Complexity untuk menemukan edge, node, predicate node dan jalur independent adalah 14. Artinya aplikasi tersebut memenuhi kriteria kompleksitas rekayasa perangkat lunak yang dapat dimengerti dengan baik.

4. Berdasarkan pengujian UAT, Aplikasi Pendeteksi Dini Penyakit Hepatitis Menggunakan Mesin Inferensi Forward Chaining Berbasis Android ini memperoleh hasil sebesar 92\%. Artinya seluruh fungsionalitas telah sesuai dengan kondisi saat dokter dan masyarakat menggunakan aplikasi tersebut.

\section{REFERENCES}

[1] A. Budiman, P. Utomo, and S. Rahayu, "Pengembangan Aplikasi Deteksi Dini Serangan Hama Padi Berbasis Android," J. Terap. Abdimas, vol. 4, no. 1, pp. 33-39, 2019, doi: 10.25273/jta.v4i1.3805.

[2] C. Hayat, Amyou, and Marcel, "Sistem Pakar Diagnosa Dini Penyakit Hepatitis dengan Metode Certainty Factor dan Dempster Shafer," J. Comput. Sci. Informatics Eng., vol. 4, no. 1, pp. 63-74, 2020.

[3] P. Sihaloho and W. Ginting, "Diagnosa Penyakit Hepatitis Menggunakan Metode Weighted Product," MEANS (Media Inf. Anal. dan Sist., vol. 02, no. 1, pp. 42-46, 2017.

[4] M. Papuangan, "Penerapan Case Based Reasoning Untuk Sistem Diagnosis Penyakit Hepatitis," JIKO (Jurnal Inform. dan Komputer), vol. 1, no. 1, pp. 7-12, 2018, doi: 10.33387/jiko.v1i1.1165.

[5] A. E. Saputri, N. Sevani, F. Saputra, and R. K. Sali, "Using Certainty Factor Method to Handle Uncertain Condition in Hepatitis Diagnosis," ComTech Comput. Math. Eng. Appl., vol. 11, no. 1, pp. 1-10, 2020, doi: 10.21512/comtech.v11i1.5903.

[6] R. Pratiwi, S. Andryana, and A. Gunaryati, "Diagnosa Hepatitis A Menggunakan Metode Dempster - Shafer," J. ELTIKOM, vol. 4, no. 1, pp. 11-21, 2020, doi: 10.31961/eltikom.v4i1.156.

[7] R. Helilintar, S. Rochana, and R. A. Ramadhani, "Sistem Pakar Diagnosis Hepatitis Menggunakan Metode K-NN untuk Pelayanan Kesehatan Primer," in Seminar Nasional Teknologi Informasi, Komunikasi dan Aplikasinya (SNATIKA), 2017, vol. 4, no. 1, pp. 19-23.

[8] S. Nurhena, N. A. Hasibuan, and K. Ulfa, "Sistem Pakar Mendiagnosa Virus Mayora Dengan Metode Variable Centered Intelligent Rule System (VCIRS)," KOMIK (Konferensi Nas. Teknol. Inf. dan Komputer), vol. 2, no. 1, pp. 95-101, 2018, doi: 10.30865/komik.v2i1.916.

[9] D. Darsin and M. F. Sesunan, "Perancangan Sistem Pendiagnosa Penyakit Hepatitis Dengan Metode Case Based Reasoning (Cbr)," J. Sist. Inf. dan Sains Teknol., vol. 1, no. 2, pp. 1-7, 2019, doi: 10.31326/sistek.v1i2.471.

[10] S. Surahman and E. B. Setiawan, "Aplikasi Mobile Driver Online Berbasis Android Untuk Perusahaan Rental 
JAST : Journal of Applied Science and Technology

Volume. 1 Number. 2, July 2021

ISSN : 2775-4022

http://jurnal.unissula.ac.id/index.php/JAST

Kendaraan," J. Ultim. InfoSys, vol. 8, no. 1, pp. 35-4

[11] Indrajani, R. Bahana, R. Kosala, and Y. Heryadi, "Aplikasi Informasi Kesehatan dan Diagnosa Penyakit Jantung Berbasis Android," in Seminar Nasional Teknologi Informasi, Komunikasi dan Industri (SNTIKI), 2018, no. 10, pp. 10-16.

[12] P. A. Putri and H. Mustafidah, "Sistem Pakar untuk Mendiagnosa Penyakit Hati Menggunakan Metode Forward Chaining (Expert System for Diagnosing Liver Disease Using Forward Chaining )," J. Inform., vol. 1, no. 4, pp. 143-155, 2011.

[13] T. R. Latifatul Khairiah, Tursina, "Sistem Pakar Diagnosis Penyakit Hati Dengan Metode Dempster Shafer Berbasis Android," J. Coding Sist. Komput. Untan, vol. 5, no. 2, pp. 57-66, 2017.

[14] M. Wyzer, Y. Durachman, and V. Arifin, "Aplikasi Penjualan Produk Alat Musik Berbasis Web ( Studi Kasus PT . Duta Karya Musikindo Jakarta ),” Stud. Inform. J. Sist. Inf., vol. 4, no. 1, pp. 1-7, 2011.

[15] P. T. Ritonga, N. I. Hutabarat, and M. H. Butarbutar, "Sistem Pakar Mendiagnosa Penyakit Hepatitis Pada Ibu Hamil Dengan Menggunakan Metode Certainty Factor," in Prosiding Seminar Nasional Multidisiplin Ilmu, 2020, no. 4, pp. 1246-1253.

[16] R. F. Heriansyah, "Sistem Pakar Diagnosa Penyakit Gigi Menggunakan Metode Forward Chaining Berbasis Web," Fountain Informatics J., vol. 4, no. 1, pp. 14-24, 2019.

[17] I. P. Sari, A. Priyanto, and R. Ananda, "Sistem Pakar Berbasis Android Diagnosis Penyakit Hepatitis Menggunakan Metode Certainty Factor dengan Penelusuran Forward Chaining," J. Edukasi dan Penelit. Inform., vol. 6, no. 3, pp. 393-400, 2020. 